\title{
A Framework for Stakeholder Analysis of Forest and Wood-Based Industry Clusters - Case Study at the State of North Rhine-Westphalia, Germany
}

\author{
Thorsten Mrosek ${ }^{*}, 1$, Mechthild A $\beta m_{a n n}{ }^{1}$, Uwe Kies ${ }^{1}$, S. Denise Allen ${ }^{2}$ and Andreas Schulte ${ }^{1}$ \\ ${ }^{I}$ Center for Forest Ecosystems, University of Münster, Robert-Koch-Straße 27, D-48149 Münster, Germany \\ ${ }^{2}$ Sustainable Forest Management Research Group, Faculty of Forestry, University of British Columbia, 2045-2424 \\ Main Mall, Vancouver BC, V6T 1Z4, Canada
}

\begin{abstract}
Concepts and methods for stakeholder analysis in forestry need further development and refinement in the context of the cluster concept and there is a lack of suitable information concerning the communication and cooperation patterns between stakeholders of the different industry branches and along the chain of production and value-adding.

Within this research project, a framework for stakeholders analysis of forest and wood-based industry clusters was developed and tested as a case study at the State of North Rhine-Westphalia (NRW) in Germany.

The study is based on methods of cluster and stakeholder analysis as well as the analysis and assessment of stakeholder and corporate networks. The case study was carried out based on a questionnaire survey among 632 stakeholder organizations (response rate $35.9 \%$ ).

The framework consists of three moduls: stakeholder identification, stakeholder analysis and assessment, and stakeholder networking and cluster management. The NRW forest sector is characterized by more than 630 stakeholder organizations, covering a wide range of industry branches and different spatial scales. The institutional characteristics vary highly. Stakeholder communication and cooperation mostly takes place between directly linked industry branches along the chain of production and value-adding. Recommendations for improved communication and cooperation include the establishment or further development of cooperation platforms or networks.
\end{abstract}

The presented framework supports stakeholder analysis under the cluster perspective. If applied in a consistent and transparent way, the framework of stakeholder analysis can contribute to more holistic, standardized, replicable and comparable descriptions of forest and wood-based industry clusters in Europe and abroad.

Keywords: Stakeholder analysis, framework, cluster concept, forest and wood-based industry clusters, forest sector, forest policy, case study, North Rhine-Westphalia, Germany.

\section{INTRODUCTION}

\subsection{Background}

The forest sector consists of a wide range of industry branches, ranging from forestry over wood processing industries (e.g. sawmilling and wood-based panel industry), wood manufacturing industries (e.g. furniture and wood construction industry) and other wood-based industries (e.g. pulp and paper industry) to non-timber forest products and services (e.g. forest-based tourism) [1, 2]. Forest and woodbased industries can show spatial agglomerations. However, from a policy and socioeconomic perspective, mostly administrative units are applied for describing the forest sector at different spatial scales (international, national, subnational/regional, local). The forest sector is also characterized by a complex policy arena with a large number of different stakeholder groups representing the different

Address correspondence to this author at the Center for Forest Ecosystems, University of Münster, Robert-Koch-Straße 27, D-48149 Münster, Germany; Tel: +49(0)228-18032000; Fax: +49(0)228-18032001;

E-mail: thorsten.mrosek@web.de industry branches and the different spatial scales [3]. In order to describe the complex forest sector with its different industries branches, which share the common ressource wood and which are connected by chains of production and value-adding, in a more holistic and integrative way, applying the cluster concept to forestry has become popular in Europe and abroad [4-6].

Industrial clusters are generally defined as spatial agglomerations of companies of related industry branches and chains of production and value-adding. Within a cluster, industry branches and their individual companies as well as related institutions (e.g. Governmental and research organizations) are linked to each other by close relationship to a certain use of resources or form of production, by spatial clustering and by high connectivity in terms of business and support activities. The overall goal of the cluster concept is to generally support these industry branches and their companies by optimizing production and value-adding processes within and between different branches (e.g. improving productivity, innovation and marketing through increased communication and cooperation). In addition to increasing the competitiveness of the industrial sector 
through measures of cluster management and political cluster support programs, the concept also aims at supporting the cluster area in its overall socioeconomic development [712]. Besides various thematic variations of the cluster concept, it is generally seen as suitable to increase innovation in the business environment of cluster area [13, 14]. Because of the popularity of the cluster concept in economic policy, there is a certain risk that the application of the concept is driven more by political development goals rather than by actual industry agglomerations ("wishful thinking" cluster initiatives) $[15,16]$. Other forms of industry self-organization, usually not all applied in the forest sector though, include industrial districts, corporate and stakeholder networks, innovation centers or milieus and regional development [8, 17-19].

With regard to the forest sector, the scientific background for cluster organization is still limited. For Europe, a basic definition of the forest and wood-processing industries cluster was developed by the European Commission. This definition included the following industry branches: wood processing and manufacturing, pulp and paper processing and manufacturing, wood-based packaging, and printing and publishing. Furthermore, it identified a strong interdependent linkage between the wood-processing industry and forestry. It focussed on the socio-economic and political importance of the forest sector and aimed at ensuring it's long-term competitiveness on global markets [20].

For Europe, several studies were carried out in order to analyze clusters of forest and wood-based industries at different spatial levels (e.g. the entire EU or countries) [4, 5, 21-24]. Examples of application of the cluster concept at the national or sub-national level are found in Finland, Sweden and Austria [24-26]. In Germany, the cluster concept has been applied at various levels, ranging from the national [27$30]$ and State [31-39] to the regional $[40,41]$ and local level [42].

Further examples for the application of the cluster concept in forest and wood-based industries outside Europe can be found within the United States of America [43, 44], Canada [45], South America [46], Russia [47] and Ukraine [48].

Examples for methodological developments and discussions concerning the cluster concept in forestry can be found in the area of spatial and statistical analysis [49-51], management [29, 52] and marketing [53].

When applying the cluster concept to the forest sector, the policy arena and the composition of stakeholders are more complex. Consequently, also stakeholder analysis is more complex in comparsion to analyzing individual industries. Concepts and methods for stakeholder analysis in forestry need further development and refinement in the context of the cluster concept and there is a lack of suitable information concerning the communication and cooperation patterns between stakeholders of the different industry branches and along the chain of production and value-adding [54].

\subsection{Research Project}

Based on the existing scientific knowledge and case study experiences in the field of industrial clusters in the forest sector as well as addressing the need for further research and field testing, the objectives of this research project were to develop a framework for analyzing stakeholders of forest and wood-based industry clusters, and to test this framework as a case study at the State of North Rhine-Westphalia (NRW) in Germany. The overall research question of the study presented was: Can a modular analysis framework effectively support data collection for stakeholder analysis of forest and wood-based industry clusters?

The research project was carried out from 2006 to 2007 with field data collection taking place in 2006. The project was based on several studies related to the forest and woodbased industry cluster of NRW, which took place between 2001 and 2006 or which are still ongoing [37, 39].

The forest sector of NRW was selected as a case study because it represents a large industry of Germany that holds international significance (e.g. in terms of forest resources, industry production and export capacity, technology and innovation) and in addition, extensive data is available for this industry (e.g. in form of an extensive database of stakeholders of the forest and wood-based industry cluster). Case study results from the forest sector of NRW were seen as relevant for comparability in the European context and for nations with major forest industry sectors abroad.

\section{METHODOLOGY}

\subsection{Study Area}

NRW is one of the 16 federal states of Germany and it is located in the western central part of Germany, bordering the Netherlands and Belgium. It covers an area of 34.1 ths. $\mathrm{km}^{2}$ and with about 18 million citizens NRW is one of the largest population concentration within Germany and Europe. Accounting for $21.7 \%$ of the German Gross Domestic Product (541.1 billion Euro in 2008) [55], NRW is also a region of major economic importance within Germany and Europe.

NRW is characterized by a long tradition of sustainable forestry and it shows a high concentration of wood-based industries. With forest coverage of $26 \%(915,800 \mathrm{ha})$ and a total merchantable timber volume (under bark) of 194.4 million $\mathrm{m}^{3}$, abundant wood resources are available on a longterm basis. $52 \%$ of the forest consists of deciduous stand types and corresponding tree species, the remaining $48 \%$ are composed of coniferous stand types and tree species. The forest ownership is characterized by a large share of private owners $(65 \%)$, in addition to $19 \%$ municipal, $13 \%$ state and $3 \%$ federal ownership. The privately owned forest area is distributed over a large number of owners $(>150,000)$, managing mostly small parcels of forest land $[56,57]$. The forest and wood-based industry cluster of NRW consists of about 200,000 employees and a turnover of approximately 40 billion Euro, making this forest and wood industry cluster the strongest within Germany and one of the most significant ones within Europe [37, 39, 49, 57].

Just as in Germany in general, the forest and forest-based industry of NRW is organized and represented in a heterogeneous way. Most industries are represented in the form of industry associations, some also in the form of cooperatives (e.g. forestry). Some industry branches of the 
sector (e.g. sawmill industry) are represented at the state level, some (e.g. forestry, wood craft) are also organized at the regional level and some industry branches (e.g. wood panel industry, pulp and paper industry) are represented only at the federal level. In this context, NRW was also seen as a suitable case study because a larger number of federal industry associations are based in this state [57].

\subsection{Methods}

The development of the framework for stakeholder analysis of forest and wood-based industry clusters was based on scientific concepts and methods of stakeholder analysis as well as the analysis and assessment of stakeholder and corporate networks [58-60]. Within the development of the framework, the focus was on methods and case study experiences from stakeholder and network analysis in the field of forestry [3, 61, 62]. Another priority within stakeholder analysis was institutional characteristics and communicative and cooperative behaviour of organizations [58, 59].

The overall context for the framework for stakeholder analysis in forestry was the concept of forest and woodbased industry clusters. Various scientific definitions $[5,6$, $20,52]$ and case studies $[4,5,28,30,37,39]$ of forest and wood-based industry clusters within Europe and abroad were considered in the design of the framework for stakeholder analysis, most relevant in the context of defining relevant industry branches and stakeholder groups.

Based on recent definitions of forest and wood-based industry clusters $[5,6,20,52]$ and based on corresponding case studies relevant for the study area of NRW [37, 39, 57], these industry branches were selected for the framework of stakeholder analysis:

- Forestry (forest companies, forest owners, forest services)

- Wood-processing industry (sawmill industry, woodbased panel industry, other roundwood processing industries)

- Wood manufacturing industry (wood construction industry, furniture industry, wood-based packaging industry, wood craftsmanship, other wood manufacturing industries)

- $\quad$ Pulp and paper industry (producing and manufacturing of pulp and paper)

- Other wood-based industries (wood trade and transportation, wood energy use)

- Wood related ancillary industry (e.g. machinery for forestry and for wood and pulp and paper processing and manufacturing)

- Non-timber forest products and services (e.g. forestbased tourism, forest education)

- $\quad$ Other forest- or wood-related institutions (e.g. relevant Governmental bodies, research and educational institutions)

The testing of the framework for stakeholder analysis of forest and wood-based industry clusters as a case study at the
State of NRW, Germany, was based on a questionnaire survey among industry stakeholders being identified as relevant. Stakeholders were defined as organizations or interest groups representing and supporting a relevant industry branch of the cluster $[3,61]$. The most relevant types of stakeholders considered within the study were industry associations, small company associations or cooperatives and public institutions. Among typical goals and activities of stakeholders selected were: coordination of member activities, informational and technical support, marketing and sales, qualification of members, public relations and lobbying. Individual companies were not considered as stakeholders although some organizations or cooperatives were also involved in business activities to some extent (e.g. State forest service agencies, small private forest owner associations).

The survey took place in the form of a written questionnaire, which was organized in six sections (additional to an over page with a description of the study and organizational information) [63, 64]:

- General information on the organization (e.g. contact information)

- Institutional characteristics (e.g. type of organization, number of staff, annual budget and source of funding, goals and activities, spatial range of responsibility or activities)

- Communication within the forest and wood-based industry cluster of NRW (e.g. within the own industry branch, with all other industry branches, type of communication)

- Cooperation within the forest and wood-based industry cluster of NRW (e.g. within the own industry branch, with all other industry branches, type of communication)

- Recommendations for improved communication and cooperation within the forest and wood-based industry cluster of NRW (e.g. improved networking, specific activities, cluster management)

\section{- $\quad$ Other (open ended question)}

Within the questionnaire, questions were grouped in sections. Within each section, mostly closed questions with four answer categories and one additional neutral answer category were used. As an example, options for answering a question like "Please describe your communication with the wood-processing industry (e.g. sawmill industry, wood-based panel industry)" were: "very important", "important", "not very important", "not important" and "not applying". In addition, each section included an open-ended questions allowing for not specified input into the survey $[63,64]$.

For the identification and selection of relevant stakeholders for consideration within the survey, an extensive database of organizations and companies of the forest and wood-based industry cluster of NRW was available. This database was created, extended and updated in the context of several previous research projects on the forest and wood-based industry cluster of NRW [7, 39, 40-42, 57, 65]. In consequence, the database allowed for a complete review of all relevant organizations and for the selection of suitable stakeholders. In total, 632 organizations were selected. The organizations identified and contacted within the survey are shown in Table 1. 
Table 1. Organizations identified and contacted as well as replying within the stakeholder analysis of the forest and wood-based industry cluster of the state of North Rhine-Westphalia

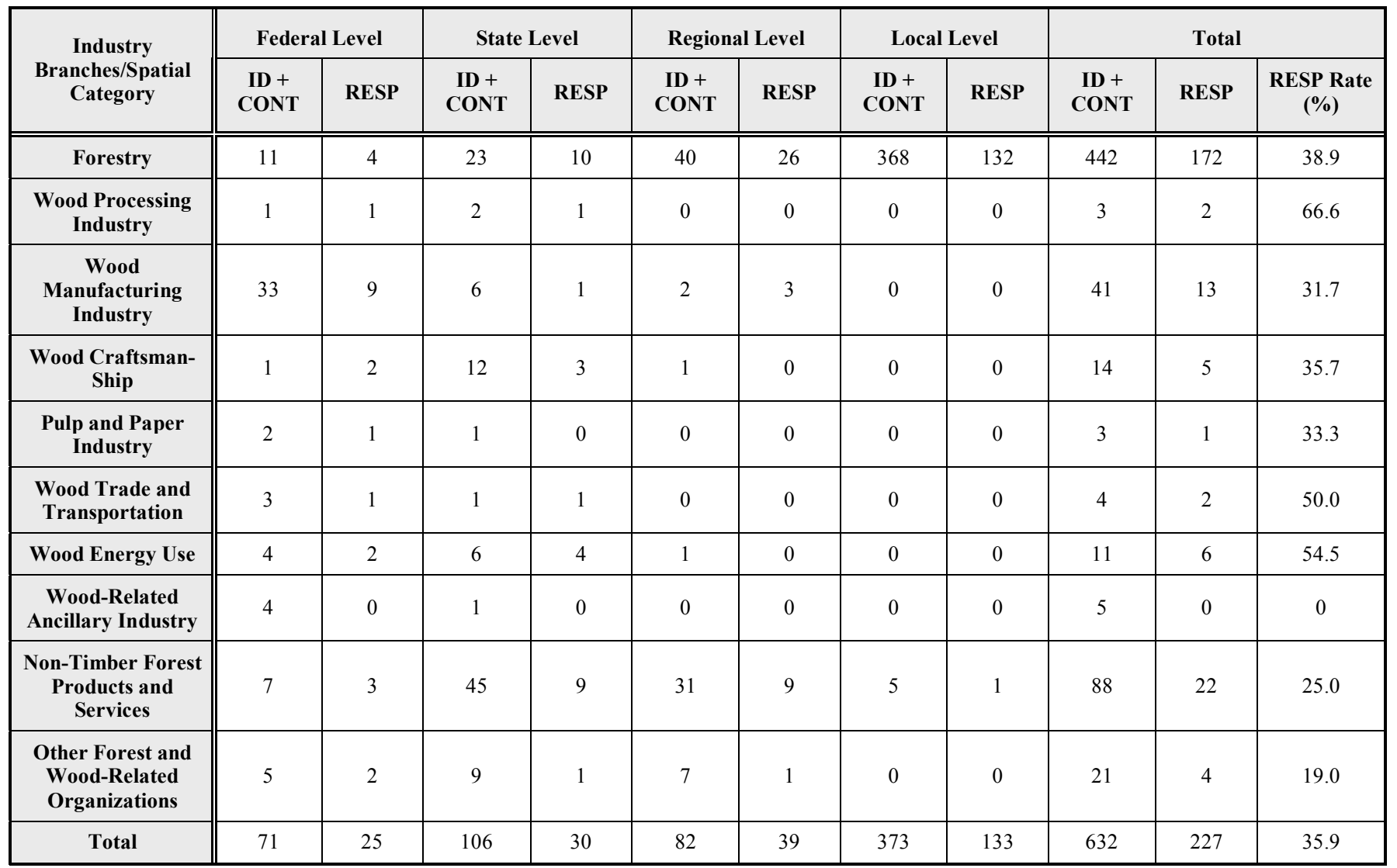

For the main industry branches of the forest and woodbased industry cluster (forestry, wood processing industry, wood manufacturing industry, pulp and paper industry, wood trade and transportation industry, forest education - as part of non-timber forest products), the coverage of stakeholders is seen as complete at all scales (local, regional, state, national). Forestry dominates the dataset in terms of numbers of stakeholders due to a large number of small private forest owner associations. For some other industry branches (wood craftsmanship, wood energy use, wood-related ancillary industry, forest tourism and forest conservation and other parts of non-timber forest products), coverage at the subState level (regional, local) is lacking. These characteristics of the dataset and the impact on the results of the stakeholder analysis are addressed in the discussion chapter.

The questionnaires were sent out by mail and addressed prepaid return envelopes were included. After four weeks a follow-up by phone took place in order to increase overall return and coverage of all industry branches. In total, 227 organizations replied to the survey, leading to an overall response rate of $35.9 \%$. The response rate for each industry branch is presented in Table 1. In comparison to usual response rates of social science surveys [63, 64], the total response rate of $35.9 \%$ is high. With the exception of the wood-related ancillary industry (no response), the response rates of all industry branches is also high, ranging from $19 \%$ (other forest and wood-related organizations) to $66 \%$ (forestry). Data processing and analysis took place applying standard database and statistics software.

\section{RESULTS}

\subsection{Framework for Stakeholder Analysis of Forest and wood-Based Industry Clusters}

The framework of stakeholder analysis of forest and wood-based industry clusters is shown in Fig. (1).

The framework consists of three major modules, each with three categories. The modules are organized in a logical sequence with feedback loops. Therefore, within the framework, stakeholder analysis is understood as a process, with singular and linear or repeated and dynamic application.

The first module "Stakeholder identification" covers the identification and selection of relevant stakeholders within the industry sector. Within the category "Industry branches", the forest and wood-based industry cluster is defined in the context of a given study area and relevant industry branches are selected. The analysis can focus on main industry branches like forestry and wood processing and manufacturing or it can also include related branches like non-timber forest products and services. In the category "Spatial scale", the geographic framework and stratification is defined for the stakeholder analysis. The analysis can focus on stakeholders of the main scale of the study area or it can also include organizations within the study area, representing smaller or larger scales. Various data sources can be utilized, including scientific studies and Governmental and industry databases. 
Stakeholder identification

Industry branches

(e. g. forestry, wood processing industry, wood-manufacturing industry, wood craft, pulp and paper industry, wood energy, wood trade, non-timber forest products and services

\section{Spatial scale (international, federal, state, regional, local level (focus on scale corresponding with study area but also considering stakeholders representing larger scales if applicable))}

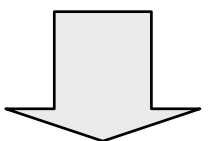

Data sources

(e. g. scientific studies, Governmental and industry databases)

\section{Stakeholder analysis and assessment}

\section{Stakeholder general institutional profile (e. g. type of organization, goals, resources, activities)}

\section{Stakeholder communication patterns} (communication within industry branch and with other industry branches within the cluster, type of communication)

\section{Stakeholder} cooperation patterns (cooperation within industry branch and with other industry branches within the cluster, type of cooperation)

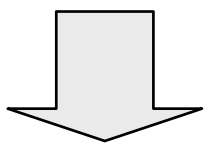

\section{Stakeholder networking and cluster management}

\section{Stakeholder} networking (communication and cooperation within industry branch and with other industry branches within the cluster, various types of communication and cooperation)

Cluster
management and
policy
development
(supporting
communication and
cooperation within
the industry cluster,
various types
network and cluster
management,
contributions to

Repeated application and refinement of method and improvement of database (e. g. validation of stakeholder database, identification of trends)

Fig. (1). Framework of stakeholder analysis of forest and wood-based industry clusters. 
The second module "Stakeholder analysis and assessment" includes the development of stakeholder profiles and the identification of stakeholder communication and cooperation patterns. The category "Stakeholder general institutional profile" deals with general characteristics like the type of the organization (e.g. industry association, public organization), its goals, resources available to the organization (e.g. staff, funding) and main activities carried out. Within the category "Stakeholder communication patterns", communicational behavior of the organization within the industry branch and concerning other industry branches of the cluster is analyzed. This includes the analysis of relevant lines of communication as well as of the extent and of different types of communication (e.g. general office communication, personal meetings, special events). The category "Stakeholder cooperation patterns" aims at analyzing the cooperation behavior of the organization within the industry branch and concerning other industry branches of the cluster. Similar to the previous category, this includes the analysis of different cooperation patterns, intensity and forms (e.g. overall business cooperation, cooperation on a project basis, marketing, public relations work, lobbying, improvement of qualification of staff resources, research and development).

The third module "Stakeholder networking and cluster management" mostly covers aspects of improving stakeholder communication and cooperation through networking and cluster management, but it also includes improvement of the concept through continued application and refinement. Within the category "Stakeholder networking", various options are provided for improving communication and cooperation within an individual industry branch and within the entire industry cluster through different networking activities (e.g. establishment and maintenance of industry networks at appropriate spatial scales, organization of joined events like trade shows, conferences and workshops, joined regional marketing, public relations and lobbying efforts, joined training of staff, implementation of joined research and development projects). The category "Cluster management and policy development" aims at supporting industry network structures and linkages and at improving framework conditions of the industry cluster, in general (e.g. knowledge base concerning industry, political support of industry). The category "Repeated application and refinement of method and improvement of database" aims at the continued validation of the concept and of the stakeholder database. Through repeated application, it also allows for the identification of long-term tends in stakeholder interaction.

\subsection{Testing of the Framework for Stakeholder Analysis of Forest and Wood-Based Industry Clusters as a Case Study at the State of North Rhine-Westphalia}

\subsubsection{Stakeholder Identification}

In general, the stakeholders of the forest and wood-based industry cluster of NRW are characterized by large number and by large heterogeneity. More than 630 organizations are involved in representing the forest and wood-based industry in NRW. As described in Chapter 2.2. "Methods" in detail, these organizations represent all relevant industry branches of the cluster (forestry, wood-processing industry, wood manufacturing industry, other wood-based industries, wood related ancillary industry, non-timber forest products and services, other forest- or wood-related institutions) and are related to different spatial scales within the study area (local, regional, state, national). The relevant stakeholders identified for the forest and wood-based industry cluster of NRW are mapped in Fig. (2).

The local stakeholders, mostly small private forest owner associations, are concentrated in the main forest areas of NRW, with the largest concentration in the region of Southern Westphalia (Südwestfalen). State and federal organizations are mostly concentrated in cities with governmental bodies: the City of Düsseldorf, the State capital, the cities of regional State districts and in the City of Bonn, the former German capital.

\subsubsection{Stakeholder Analysis and Assessment}

\section{$\underline{\text { Stakeholder General Institutional Profiles }}$}

Concerning the general institutional characteristics of the stakeholders, the resources available to the organizations vary highly. With regard to staff resources, $33 \%$ of the organizations show no full time staff, $13 \%$ have more than 20 full time staff. $65 \%$ of the organizations have no or less then six part-time employees. $45 \%$ of the organizations have between one and ten voluntary staff. Concerning organizations with member structures, 52\% have up to 300 individual members, only $7 \%$ have 301 to 1,000 members. With regard to financial resources, $33 \%$ of the stakeholders have an annual budget of more than 250,000 Euro, but $32 \%$ have a budget of less than 20,000 Euro. 51\% of the organizations create their funding independently, through membership fees or business activities, $28 \%$ are funded by the public sector. $71 \%$ of the organizations have responsibility for the management of a forest area.

The main goals and activities of the stakeholders of the forest and wood-based industry cluster of NRW are shown in Fig. (3).

Main goals and activities of the organizations are business activities like forest management (23\%) and technical support such as advice of private woodlot owners and support of their forest management activities (19\%). Lobbying and marketing and public relations activities account for 14 and 13 percent respectively. Public administration, for example carried out by offices of state and municipal forest services, accounts for $12 \%$ and professional training for $10 \%$ of goals and activities. Research and development activities play a minor role among the organizations surveyed (3\%).

Concerning the spatial mandate of the stakeholders, $59 \%$ of the organizations operate at the local level, $13 \%$ at the regional, $13 \%$ at the state and $12 \%$ at the federal level.

\section{$\underline{\text { Stakeholder Communication Patterns }}$}

The communication pattern of the stakeholders of the forest and wood-based industry cluster of NRW can be described in accordance to communication within and between the different industry branches. In general, various forms of communication were described as relevant: general office communication (described as very important by $26 \%$ and as important by $52 \%$ of the organizations surveyed), irregular personal communication (e.g. in the context of business meetings) (20\% very important and $65 \%$ important) 


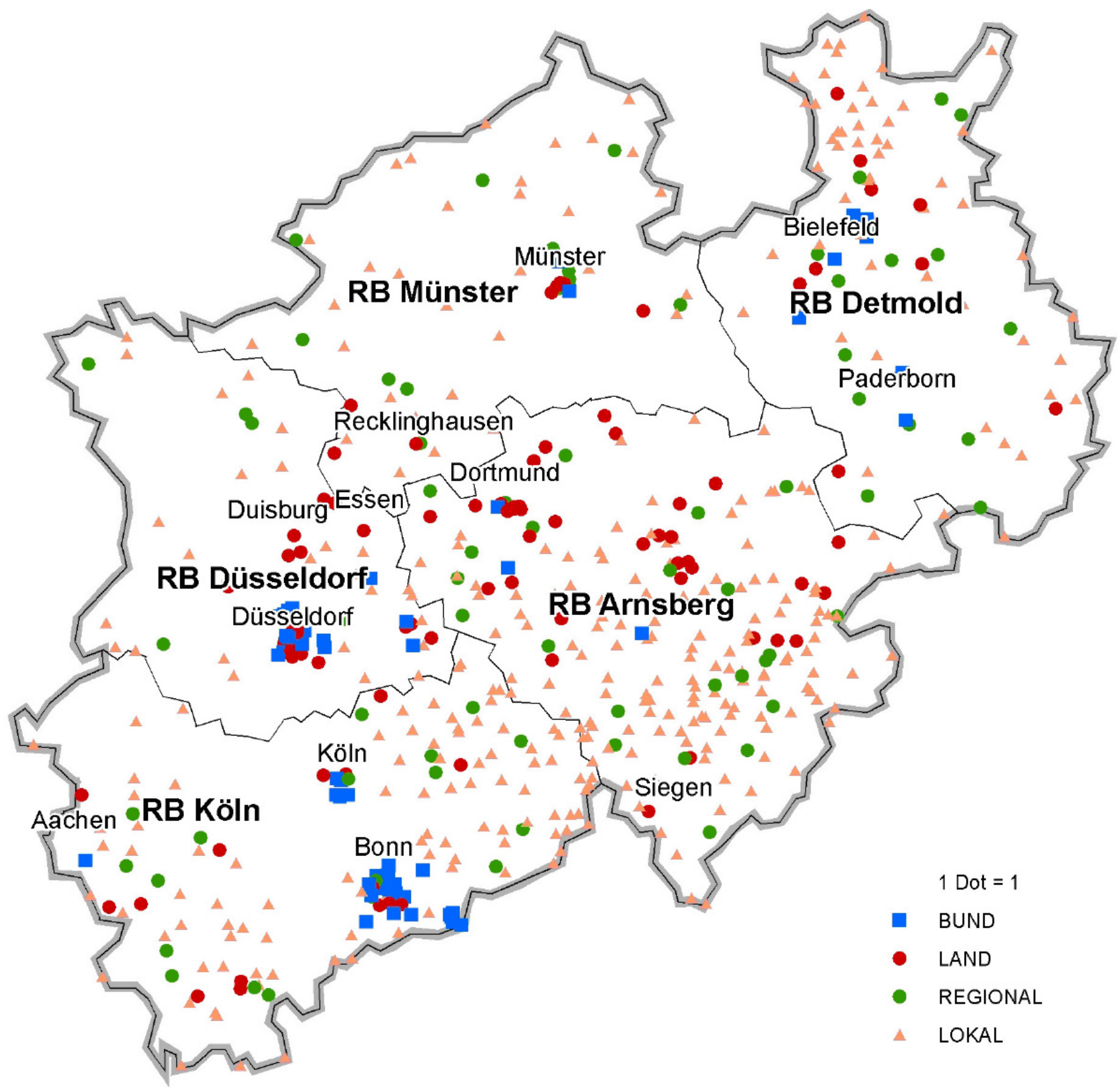

Fig. (2). Stakeholders identified for the forest and wood-based industry cluster of NRW (total of 632 organizations covering various industry branches and spatial scales; BUND = Federal level organizations, LAND $=$ State level organizations, REGIONAL $=$ regional level organizations, LOKAL = local level organizations).

and regular personal communication (e.g. in the context of events or networking activities) (30\% very important and $41 \%$ important). Although within the study, communication within and between all industry branches of the cluster was analyzed in detail, due to space limitations of this article, only main results for key industry branches are presented within this paper. (4).

The communication pattern of forestry is shown in Fig.

Forestry shows significant communication within the industry branch, $58 \%$ of the stakeholders survey describe internal communication as very important, $38 \%$ as important. Concerning communication of forestry with industry branches of the following chains of the chain of production and value-adding, interaction with the woodprocessing industry ( $26 \%$ very important, $42 \%$ important), the wood energy use (19\% very important, $45 \%$ important) and wood trade and transportation $(13 \%$ very important, $45 \%$ important) is assessed as most relevant. $16 \%$ see communication with the non-timber forest products and services sector as very important, $38 \%$ as important. Interaction with the forest- or wood-related public sector (27\% very important, $43 \%$ important) and with forest- or wood-related associations (22\% very important, $43 \%$ important) is also seen as of importance. Communication 


\section{Stakeholder goals and activities}

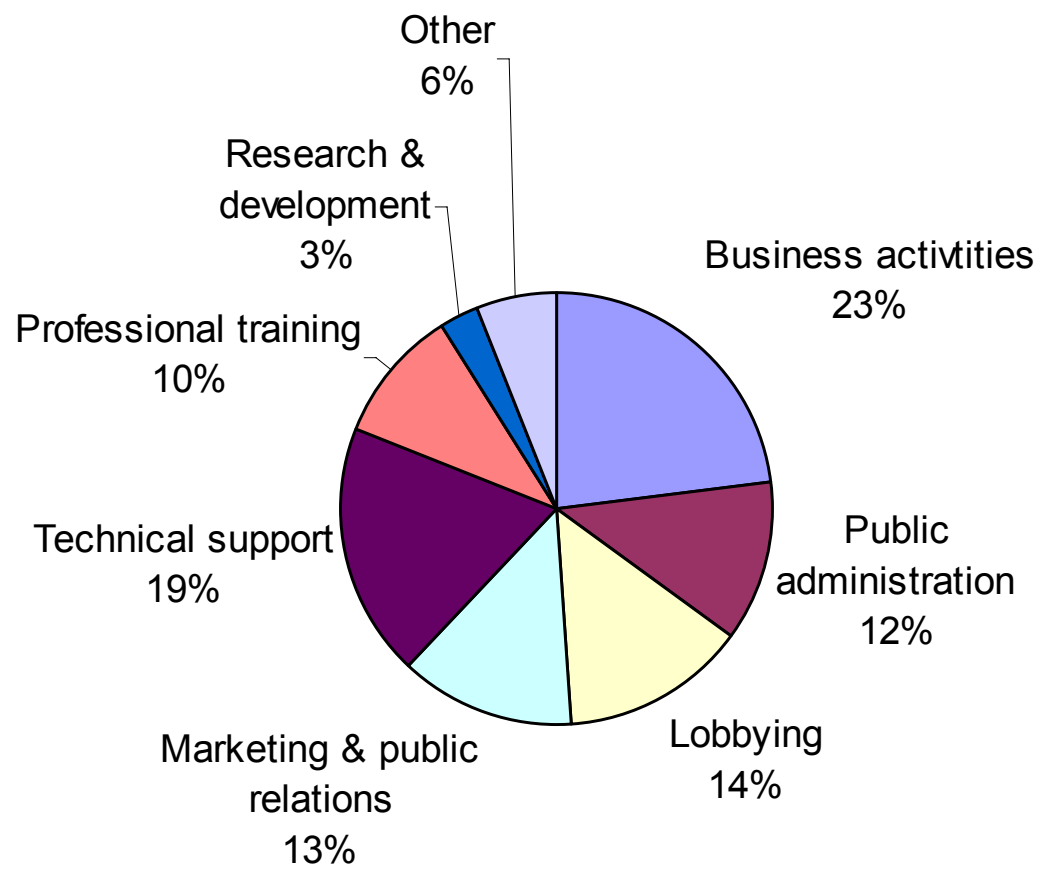

Fig. (3). Goals and activities of the stakeholders of the forest and wood-based industry cluster of NRW.

with other industry branches is described as less or not important.

For the wood-processing industry communication is described as very strong within the industry branch, with its supplier forestry and with the forest- or wood-related public sector and corresponding associations (all these categories described as very important with 100\%). Concerning communication of the wood-processing industry with industry branches of the following chains of the chain of production and value-adding, interaction with the wood manufacturing industry, the wood energy use and wood trade and transportation are also assessed as highly relevant (all these categories described as very important or important with $50 \%$ each). Interaction with forest- or wood-related education and R\&D is seen as important (100\%). 50\% of the organizations interviewed, also see communication of the wood-processing industry with wood craftsmanship and with the pulp and paper industry as very important. Interaction with other industries is seen as less or not important.

The communication pattern of the wood manufacturing industry is displayed in Fig. (5).

The wood manufacturing industry shows strong communication within the industry branch, $57 \%$ of the stakeholders survey describe internal communication as very important, $21 \%$ as important. Interaction with the wood related ancillary industry $(43 \%$ very important, $29 \%$ important) and with forest- or wood-related associations (29\% very important, 64\% important) is also assessed as highly relevant. $21 \%$ of the organizations interviewed describe the communication of the wood manufacturing industry with the forest- or wood-related education and R\&D sector as very important, $50 \%$ as important. Other industry branches described as relevant in terms of communication are the wood related financial sector (36\% very important), wood craftsmanship (14\% very important, 57\% important), the wood-processing industry (7\% very important, $64 \%$ important) and the forest- or wood-related public sector $(86 \%$ important). Communication with other industry branches is described as less or not important.

\section{$\underline{\text { Stakeholder Cooperation Patterns }}$}

Although within the study, cooperation between the different industry branches of the NRW forest cluster was analyzed in detail, due to space limitations of this article, only main results for the entire industry cluster are presented within this paper. In general, cooperation between different industry branches is high where also significant communication takes place. Types and relevance of cooperation between the different industry branches are shown in Fig. (6).

In general, more versatile types of cooperation are of higher relevance than specific types of cooperation. $22 \%$ of the organizations surveyed describe cooperation in the context of overall business activities as very important, $46 \%$ as important. Cooperation within specific business-related projects (15\% very important, $44 \%$ important) and in the context of marketing and public relations work (17\% very important, $35 \%$ important) are also described as highly relevant. Cooperation in professional training of staff resources is described as less relevant (31\% important), followed by research and development (24\% important). 


\section{Communication of forestry with industry branches}

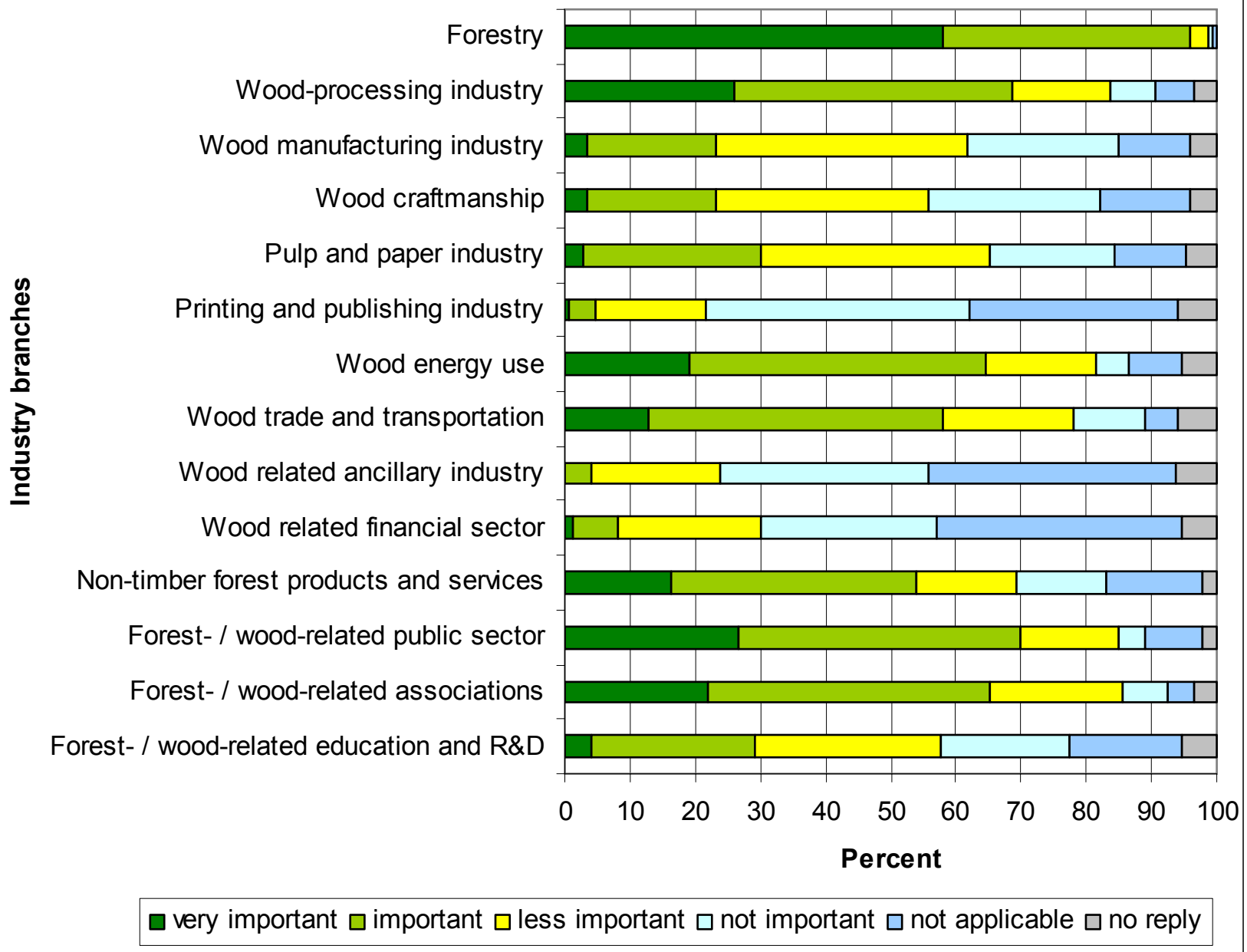

Fig. (4). Communication pattern of forestry concerning different industry branches of the forest and wood-based industry cluster of NRW (communication within forestry and with other industry branches, importance assessed by forestry stakeholders surveyed, $\mathrm{n}=172$ ).

\subsubsection{Stakeholder Networking and Cluster Management}

Although within the study, recommendations for improved communication and cooperation by the different industry branches of the forest and wood-based industry cluster of NRW were analyzed in detail, due to space limitations of this article, only main results for the entire industry cluster are presented. The main recommendations made by the stakeholders are summarized in Fig. (7).

The most important recommendation is the establishment or further development of platforms or networks of regional cooperation ( $29 \%$ very important, $44 \%$ important), followed by increasing public relations works $(20 \%$ very important, $50 \%$ important). $19 \%$ of the organizations interviewed also see the establishment or further development of platforms or networks of State-wide cooperation as very important, $43 \%$ as important. Increased and coordinated marketing beyond the regional level (nation-wide and international marketing) is seen as relevant (12\% very important, $37 \%$ important). Also increased and joined professional training for staff resources is described as relevant (10\% very important, $51 \%$ important). $41 \%$ see the increased organization of informational events for the industry as important. Increased cooperation in research and development is considered to be of lower priority ( $33 \%$ important).

The specific question concerning the relevance of Statewide cluster management shows a clear result. $75 \%$ of all stakeholders interviewed see the establishment of a central and coordinated cluster management for the forest and wood-based industry cluster of NRW as highly relevant $(21 \%$ very important, $54 \%$ important). The biggest supporters of such a State-wide cluster management are the pulp and paper industry, forestry, wood craftsmanship, wood trade and transportation as well as the wood-processing industry. 


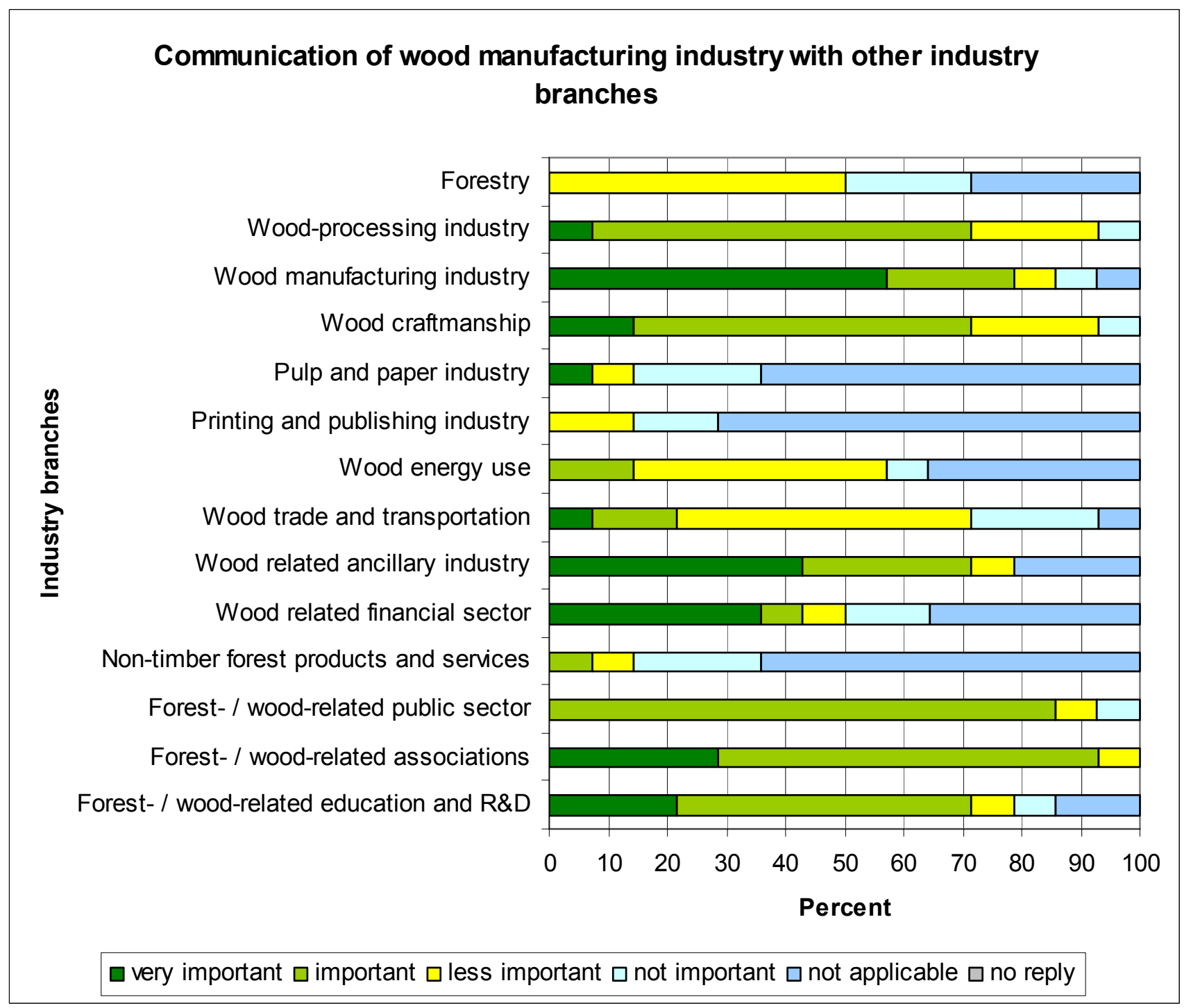

Fig. (5). Communication pattern of the wood manufacturing industry concerning different industry branches of the forest and wood-based industry cluster of NRW (communication within wood manufacturing industry and with other industry branches, importance assessed by wood-processing industry surveyed, $\mathrm{n}=14$ ).

\section{DISCUSSION}

\subsection{Framework for Stakeholder Analysis of Forest and Wood-Based Industry Clusters}

Although concepts and methods of stakeholder analysis are well established in the scientific field of forest policy [3, 61] and in policy science in general [17-19], the adaption and application of these concepts and methods to the area of forest and wood-based industry clusters is still new and suitable case study experiences are still limited. While scientific methods of stakeholder analysis and corresponding management tools often focus on the comparative analysis and assessment of individual stakeholders (e.g. identification of most relevant stakeholders for the success of business development or of a project), this paper looks at stakeholders more from an overall industry sector and policy perspective.
The framework for stakeholder analysis of forest and wood-based industry clusters presented in this paper allows for a holistic view on the wide range of industry branches of the forest- and wood-related industry sector [40, 54]. The modular structure of the analysis framework facilitates a flexible and dynamic research approach concerning forest and wood-based industry clusters with different structures and at various spatial scales. For example, based on research objectives, data availability and study resources, a cluster stakeholder analysis can focus on key industry branches like forestry, wood-processing, wood manufacturing and pulp and paper industry or it can include the full scale of relevant industry branches. The stakeholder analysis can focus on a specific study area, often defined by administrative boundaries or Governmental jurisdiction, or it can be carried out in a more open way identifying relevant industry and stakeholder concentrations and interactions at various spatial scales. In this context it is important to differentiate between 


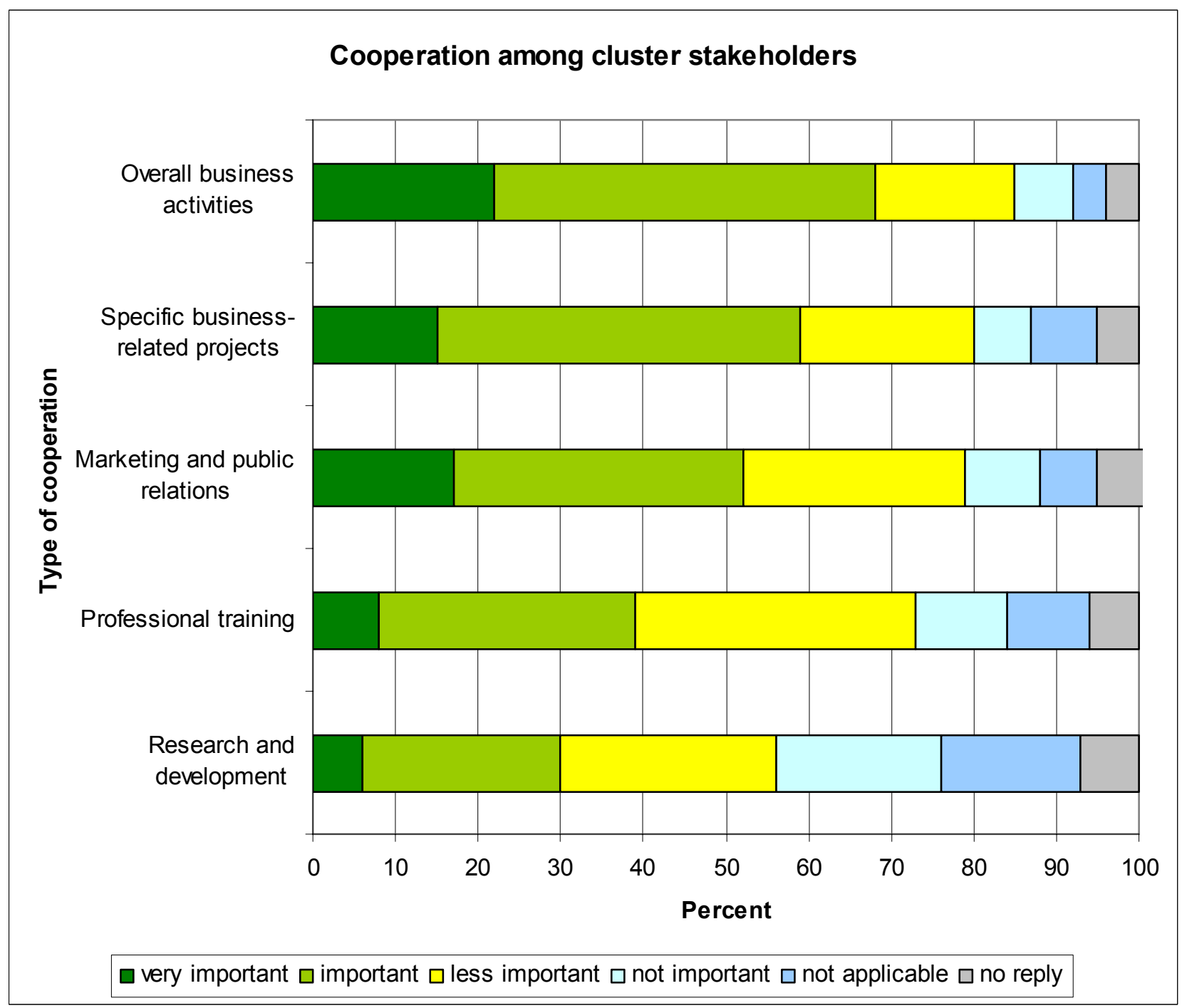

Fig. (6). Types and relevance of cooperation among the stakeholders of the forest and wood-based industry cluster of NRW ( $\mathrm{n}=227$ ).

stakeholder analysis based more on normative definitions of relevant industry branches on the one hand and on results of numerical and spatial cluster analysis on the other hand. The framework also allows for different approaches concerning data sources and data collection, based on data availability concerning relevant stakeholders. Often incomplete or poor quality data on relevant stakeholders will be the limiting factor for implementing the concept in a meaningful way.

The analysis of general institutional profiles and of stakeholder communication and cooperation patterns can take place at different levels of detail. The extent of the survey and the nature of the questions highly depend on the interview methods applied.

The framework of stakeholder analysis also produces output-oriented results in the form of recommendations for improving communication and cooperation within the industry cluster. Main approaches for improving communication and cooperation behaviour among the stakeholders are networking as well as cluster management and cluster policy development.
Because of common data limitations concerning relevant stakeholders in a given study area, the framework is designed for repeated application and continuous refinement of methods and findings.

If applied in a consistent and transparent way, the framework of stakeholder analysis presented in this paper can contribute to more holistic, standardized, replicable and comparable descriptions of forest and wood-based industry clusters in Europe and abroad. In this way, the study contributes to the further development and refinement of stakeholder-oriented concepts and analysis methods in the field of forest policy and socioeconomics.

\subsection{Testing of the Framework for Stakeholder Analysis of Forest and Wood-Based Industry Clusters as a Case Study at the State of North Rhine-Westphalia}

Concerning the testing of the framework for stakeholder analysis, the case study area of NRW proofed highly suitable because of the significant concentration forest and woodbased industries and because of the comprehensive database 


\section{Stakeholder recommendations for improved communication and cooperation}

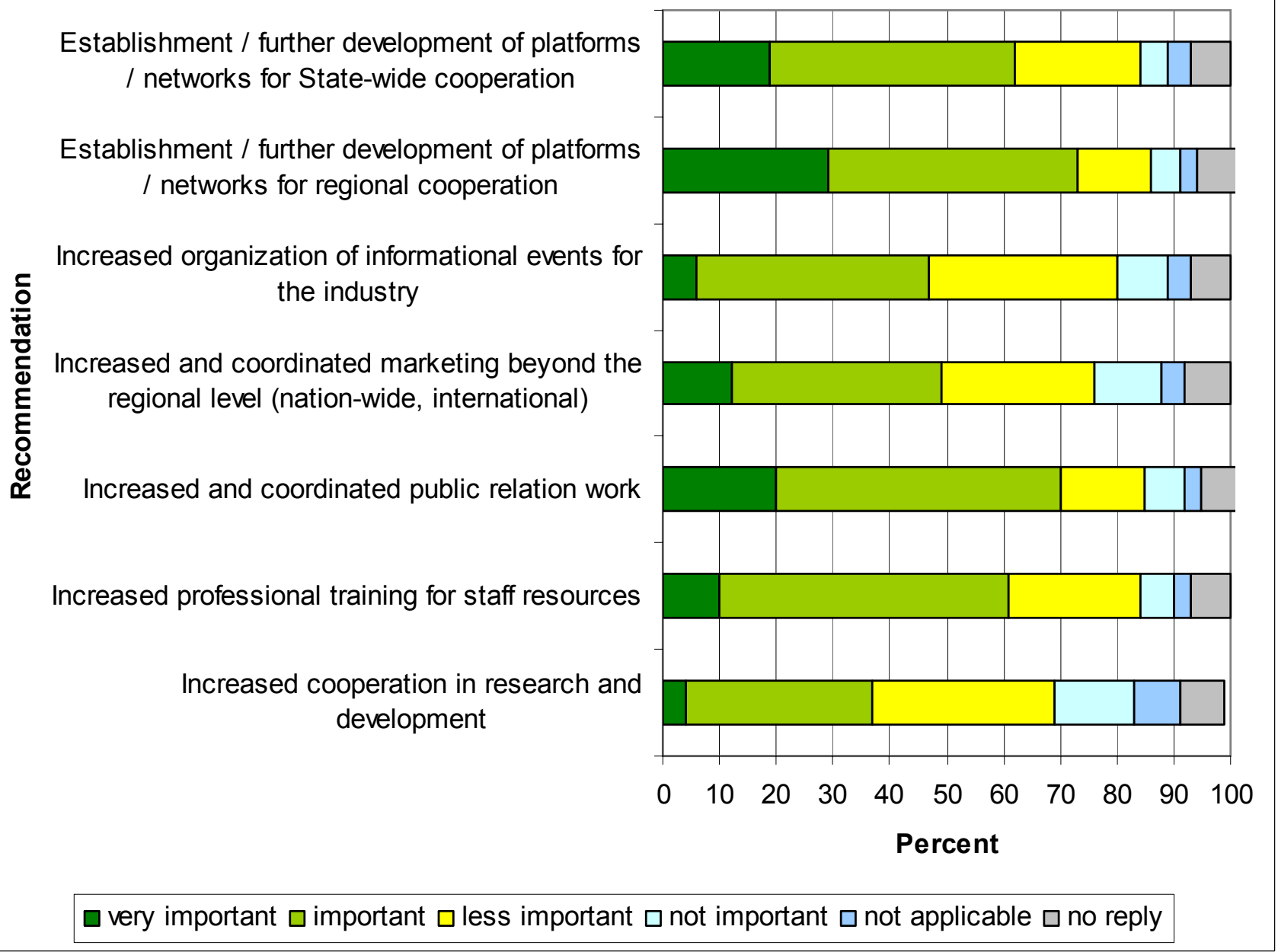

Fig. (7). Recommendations for improved communication and cooperation by the stakeholders of the forest and wood-based industry cluster of NRW $(n=227)$.

available on relevant stakeholders. Within the study, the full range of relevant industry branches was included and with 632 organizations a high number of relevant stakeholders was identified for all industry branches and at all spatial scales. The response rate was very high in total $(35.9 \%)$ and for the different data strata (ranging from 19 to $66 \%$ ) leading to overall significant results. Concerning findings for the entire data sample, the data includes a major bias towards the industry branch forestry and towards the local and regional level (172 out of the total of 227 organizations which responded to the survey belong to this category). Therefore, these findings strongly represent a forestry perspective within the industry sector. Of course, this does not effect findings for individual industry branches. For some industry branches, only a few stakeholders participated in the study (e.g. pulp and paper industry with $\mathrm{n}=1$, wood-processing industry with $n=2$ ). In these cases, findings are still relevant and meaningful because these stakeholders are main industry associations representing the entire industry branch very effectively. In general, the data showed some heterogeneity due to the wide range of industry branches included and the different spatial scales covered. Due to space limitations of this article, major differences (e.g. pulp and paper industry $v s$ non-timber forest products and services) were not presented within this paper.

The results of the study show a large heterogeneity of the stakeholders of the forest and wood-based industry cluster of NRW. With more than 600 organizations, a large number of organizations is involved in representing the industry sector. The different industry branches represented range from forestry, wood-processing and manufacturing, pulp and paper, wood products trade, wood energy use, and nontimber products and services (e.g. forest ecology and conservation, forest tourism and education). The institutional characteristics (including their resources and their consequent capacity for networking and supporting cluster development) vary highly. For example, about $30 \%$ of the organizations show annual budgets of less than 20.000 EUR, 
another $30 \%$ of more than 250.000 EUR. The goals and main activities of the organizations include management (in the case of local forest administration), technical support of forest owners and companies, lobbying, marketing and public relations, administration, and education and training.

The results indicate that overall stakeholder communication and cooperation mostly takes place between directly linked industry branches along the chain of production and value-adding. Industries being characterized and connected by a supplier-customer relationship (e.g. between forestry and the sawmill industry) show well established communication and cooperation patterns. Communication and cooperation takes place in many different forms, including typical business instruments but also personal contact at a regular basis. Communication and cooperation between organizations of other, more distant industry branches (e.g. between forestry and furniture manufacturing) is rather limited. In general, these patterns are not well established between the various industry branches of the forest sector.

Within the survey, the stakeholders provided recommendations for the improvement of communication and cooperation mechanisms. These recommendations included the extension or the establishment of regional and State-wide networking beyond the traditional structures and processes, extending coordinated public relations work for the entire forest sector, and the establishment of State-wide cluster management.

Overall, the case study demonstrated the suitability and the capacity of the framework for stakeholder analysis of forest and wood-based industry clusters. Given suitable databases on forest sector stakeholders, the method proofed relevant for stakeholder analyses in comparable forest clusters in Europe and abroad.

\section{CONCLUSIONS}

Forests and the forest- and wood-based industry sector are very important from an ecological, economic and social perspective, especially when they form an industry cluster in a certain region or country. Considering increasing challenges for the forest sector worldwide, a cluster perspective can be very helpful for showing the complex structure and the various interactions between the different industry branches and along the chain of production and value-adding. Applying the cluster concept to forestry can also be highly relevant for increasing the competitiveness of the industry and for supporting the sustainable development of the industry. Due to the complexity and heterogeneity of forest industry clusters, a large number and a wide range of different types of relevant stakeholders need to be considered in the policy arena. The analysis of cluster stakeholders and of their communication and cooperation patterns becomes a critical factor for successful cluster management and cluster policy development. Whereas the framework for stakeholder analysis of forest and wood-based industry clusters presented in this paper contributes to an improved understanding of forest clusters, further development and refinement as well as case study testing of concepts and methods is needed. However, the approach and case study presented in this paper shows that analyzing stakeholders in the forest industry sector in the context of the cluster concept can provide an improved understanding of stakeholder structures and interaction and that it can support improving communication and cooperation between stakeholders. Improved communication and cooperation between the different industry branches and along the chain of production and value-adding is the foundation for increasing the competitiveness and for supporting the sustainable development of the forest- and wood-based industry.

\section{ACKNOWLEDGEMENTS}

The authors would like to thank the representatives and experts of the forest and wood-based industry sector of NRW for participating in the survey of the study and contributing to the research project. The authors also thank Sandi Simon, Baltimore, USA, for reviewing and editing the article.

Financial support of this research project was provided by the Ministry of Environmental Protection and Nature Conservation, Agriculture and Consumer Protection of North Rhine/Westphalia (Ministerium für Umwelt und Naturschutz, Landwirtschaft und Verbraucherschutz des Landes NordrheinWestfalen) and by the Georg-Ludwig-Hartig Foundation (Georg-Ludwig-Hartig-Stiftung).

\section{REFERENCES}

[1] Bergen V, Löwenstein W, Olschewski R. Forest economy: an introduction to economics [in German]. Munich: Vahlen 2002.

[2] Schmithüsen F, Schmidhauser A, Mellinghoff S, Kammerhofer A, Kaiser B. Entrepreneurship in forest and wood industries: basics of business administration and management processes [in German]. $2^{\text {nd }}$ ed. Gernsbach: Deutscher Betriebswirte-Verlag 2008.

[3] Krott M, von Paschen R. Forest policy analysis. Dordrecht: Springer Netherlands 2005.

[4] Viitamo E. Cluster analysis and the forest sector - where are we now? Interim report IR-02-012. Laxenburg: International Institute for Applied Systems Analysis 2001.

[5] Hazley C. Forest-based and related industries of the European Union - Industrial districts, clusters and agglomerations. Helsinki: The Research Institute of the Finnish Economy 2000.

[6] Mrosek T, Schulte A. Forest and wood industry clusters: Problems, concept, experiences and outlook. [in German]. Allgemeine Forstzeitschrift/Der Wald 2004; 23: 1261-3.

[7] Porter ME. On competition. Boston: Harvard Business School Press 1998.

[8] Maier G, Tödtling F. Regional and urban economics Part 2: Regional development and policy [in German]. Vienna, New York: Springer 2002.

[9] Scherer R, Bieger T, Eds. Clustering - the promise of promotion of the economy [in German]. Bern, Stuttgart, Vienna: Paul Haupt 2003.

[10] Schiele H. The location factor: Increasing productivity and innovation of companies in the context of regional clusters [in German]. Weinheim: WILEY-VCH 2003.

[11] Sölvell Ö, Lindqvist G, Ketels C. The Cluster Initiative Greenbook. Stockholm: Ivory Tower 2003.

[12] Brenner T. Local industrial clusters: Existence, emergence and evolution. London, New York: Routledge 2004.

[13] Organisation for Economic Co-operation and Development. Boosting innovation: The cluster approach. London: OECD Publishing 1999.

[14] Bröcker J, Dohse D, Soltwedel R, Eds. Innovation clusters and interregional competition. Advances in Spatial Economics Series. Berlin, Heidelberg, New York: Springer 2003.

[15] Enright MJ. In: Bröcker J, Dohse D, Soltwedel R, Eds. Innovation clusters and interregional competition. Advances in Spatial Economics Series. Berlin, Heidelberg, New York: Springer 2003. 
[16] Kiese M, Schätzl L, Eds. Cluster and regional development. Theory, counseling and practical implementation [in German]. Dorothea: Rohn-Klewe 2008.

[17] Howaldt J, Kopp R, Flocken P, Eds. Networks for cooperation and regional modernization: Theory and practice of networking [in German]. Wiesbaden: Gabler 2001.

[18] Stahl T, Schreiber R. Regional networks as a source of innovation. The concept of ,learning regions" in Europe [in German]. Frankfurt, New York: Campus 2004.

[19] Armstrong H, Taylor J. Regional economics and policy. $3^{\text {rd }}$ ed. Malden, Oxford, Carlton: Blackwell Publishing; 2000.

[20] Commission of the European Union. Communication on the State of Competitiveness of the EU Forest-Based and Related Industries. Communication of the Council, the European Parliament, the Economic and Social Committee and the Committee of the Regions. COM 457. Brussels: Commission of the European Union; 1999.

[21] Hanzl D, Urban W. Competitiveness of industry in candidate countries. Forest-based industries. Vienna: Vienna Institute for International Economic Studies 2000

[22] Viitamo E, Bilas O. Competitiveness of the Forest Sector in the EU Candidate Countries - Cluster Analysis. Interim report IR-01-016. Laxenburg: International Institute for Applied Systems Analysis 2002.

[23] United Nations Economic Commission for Europe and Food and Agriculture Organization. European Forest Sector Outlook Study. Main report. ECE/TIM/SP/20. Geneva Timber and Forest Study Paper. Geneva: United Nations Economic Commission for Europe and Food and Agriculture Organization 2005.

[24] European Cluster Observatory. European cluster organisation directory Q4 2009. 2009 [cited 2009 December 8]. Available from http://www.clusterobservatory.eu/upload/directory.pdf

[25] Competitiveness, 2008. The clustering efforts of the forest industry in Finland. [cited 2009 December 8]. Available from http://www.clusterobservatory.eu/upload/Europe_Innova_Cluster_ Mapping-Case_Forest_Finland.pdf

[26] Swedish Forest Industries Federation. The Swedish forest industries. Facts and figures 2008. Stockholm: Swedish Forest Industries Federation, Stockholm 2009.

[27] Seintsch B. Development of the forest and wood industry cluster. Study "Economic relevance of the forest and wood industry cluster" in the context of the Federal study "Cluster analysis of the forest and wood industry". [in German]. Holz-Zentralblatt 2008; 49: 1390-1.

[28] Mrosek T, Kies U, Schulte A. Cluster analysis of the forest and wood industry of Germany 2005. Forest and wood industry shows high relevance in terms of economics and labor policy [in German]. Holz-Zentralblatt 2005; 84: 1113-7.

[29] Mrosek T, Kies U. Cluster management in the forest and wood industry. Recommendations in the context of the cluster analysis of the forest and wood industry of Germany [in German]. HolzZentralblatt 2006; 29: 841-3.

[30] Dieter M, Thoroe C. The forest and wood industry in Germany in accordance to the new European industry sector definition. [in German]. Forstwissenschaftliches Centralblatt 2003; 122: 138-51.

[31] Klein D, Kies U, Schulte A. A description of the forest and wood industry of Mecklenburg-Western Pomerania. Unexpected high economic relevance of the forest and wood industry [in German]. Holz-Zentralblatt 2009; 10: 256-8.

[32] Cluster-Initiative Forst und Holz in Bayern, Ed. Cluster analysis of the forest and wood industry of Bavaria 2008 [in German]. Freising: Cluster-Initiative Forst und Holz in Bayern 2008.

[33] Jaensch K, Harsche J. The forest and wood industry cluster of Hesse. Actual state analysis and potential for future development [in German]. Wiesbaden: Hessen Agentur GmbH 2007.

[34] Rüther B, Hansen J, Ludwig A, et al. Cluster analysis of the forest and wood industry of Lower Saxony. [in German]. Beiträge aus der Nordwestdeutschen Forstlichen Versuchsanstalt. Göttingen: Universitätsverlag 2007

[35] Ministerium für Ländliche Entwicklung, Umwelt und Verbraucherschutz des Landes Brandenburg, Ed. The forest and wood industry cluster of Brandenburg: Current state and perspectives. [in German]. Potsdam: Ministerium für Ländliche Entwicklung, Umwelt und Verbraucherschutz des Landes Brandenburg 2005.
[36] Kramer M, Möller L. Structural analysis and market analysis of the forest and wood industry cluster of Saxony and of selected regions in Lower Silesia and Northern Bohemia under the conditions of the enlargement of the EU to the East. [in German]. Zittau: Internationales Hochschulinstitut Zittau 2006.

[37] Schulte A, Mrosek T, 2006. Analysis and assessment of the forestry and wood-based industry cluster in the State of North Rhine-Westphalia, Germany. FORSTARCHIV 2006; 4: 136-141

[38] Seegmüller S. The forest and wood industry cluster of RhinelandPalatinate. [in German]. Trippstadt: Forschungsanstalt für Waldökologie und Forstwirtschaft Rheinland-Pfalz, Struktur- und Genehmigungsdirektion Süd 2005 .

[39] Schulte A. A description of the forest and wood industry of North Rhine-Westphalia. Unexpected high economic relevance of the forest and wood industry. [in German]. Holz-Zentralblatt 2003; 74: 1018-1019.

[40] Mrosek T, Kies U, Martinsohn A, Allen SD, Schulte A. In: Kant S, Tzschupke W, Peyron, JL, Jöbstl H, Eds. Managerial economics and accounting in an evolving paradigm of forest management. Rottenburg am Neckar: Hochschule für Forstwirtschaft Rottenburg 2008; 48-69.

[41] Kies U, Martinsohn A, Mrosek T, Schulte A. Forest and Wood Network Eifel. Information basis for network management in the forest and wood industry cluster of the Eifel region [in German]. Münster: University of Münster 2008.

[42] Mrosek T, Kies U, Martinsohn A. Study concerning the forest and wood industry cluster of the City of Arnsberg. Cluster analysis and recommendations for cluster management at the local level. [in German]. Forst und Holz 2006; 6: 217-220.

[43] Rojas TD. National forest economic clusters: a new model for assessing national-forest-based natural resources products and services. General Technical Report PNW-GTR-703. Portland: United States Department of Agriculture, Forest Service, Pacific Northwest Research Station 2007.

[44] E.D. Hovee \& Company, F.P. Marketing Solutions., Oregon Forest Resources Institute, Eds. Oregon forest sector contributions and potential. Vancouver, Washington: E.D. Hovee \& Company 2004.

[45] Ottawa Valley Economic Development Office, Eds. Central and Eastern Ontario. Healthy Forests, healthy businesses. Pembroke: Ottawa Valley Economic Development Office, Pembroke 2001

[46] Bonita M, Correa F, Veijalainen P, Ahveninen H. Forest clusters: A competitive model for Latin America. Washington: Inter-American Development Bank, Sustainable Development Department 2002.

[47] Dudarev G, Boltramovich S, Efremov D. From Russian forests to world markets. A competitive analysis of the Northwest Russian forest cluster. Helsinki: International Institute for Economics and Strategy Studies 2002

[48] Androsov K, Jurynetz O. The Carpathians of Ukraine as developing region. International research group presents results of a cluster analysis of the region of the Carpathians of Ukrain [in German]. Holz-Zentralblatt 2009; 10: 259

[49] Kies U, Mrosek T, Schulte A. A statistics-based method for cluster analysis of the forest sector at the national and sub-national level in Germany. Scand J Forest Res 2008; 23: 445-457.

[50] Kies U, Mrosek T, Schulte A. Spatial analysis of regional industrial clusters in the German forest sector. Int Forestry Rev 2009; 11: 3851.

[51] Klein D, Kies U, Schulte A. Regional employment trends in Germany's forest cluster: a comparative shift-share analysis of post-reunification development. Eur J Forest Res 2009; 128: 205 219.

[52] Mrosek T, Tesch D, Kies U, Schulte A. Forest and wood industry clusters. Cluster analysis and management at different spatial scales [in German]. Forst and Holz 2005; 6: 239-243.

[53] Schanz H. Clusters and market chains - Potential and limitations of integrative marketing approaches in the forest and wood industry [in German]. Forst and Holz 2007; 62: 27-31.

[54] Mrosek T, Schulte A. In: Reynolds KM, Kohl M, Thomson A, Shannon MA, Ray D, Rennolls K, Eds. Sustainable forestry: From monitoring and modelling to knowledge management and policy science. Oxfordshire, CABI Publishing 2007; pp. 145-58.

[55] Arbeitskreis "Volkswirtschaftliche Gesamtrechnungen der Länder". Economical statistics for the States [in German]. Statistische Ämter des Bundes und der Länder [serial on the internet]. 2009 December; [cited 2009 December 8]. Available from: http://www.vgrdl.de/Arbeitskreis_VGR/ 
[56] Ministerium für Umwelt und Naturschutz, Landwirtschaft und Verbraucherschutz des Landes Nordrhein-Westfalen. State Forest Report North Rhine-Westphalia. [in German]. Düsseldorf: Ministerium für Umwelt und Naturschutz, Landwirtschaft und Verbraucherschutz des Landes Nordrhein-Westfalen 2007.

[57] Schulte A, Eds. Forests of North Rhine-Westphalia [in German] Münster: Aschendorff; 2003.

[58] Becker T, Dammer I, Howaldt J, Killich S, Losse A, Eds. Network management - Business success through cooperation [in German]. $2^{\text {nd }}$ ed. Berlin, Heidelberg, New York: Springer 2007.

[59] Chrisholm RF. Developing network organizations. Learning from practice and theory. 3rd ed. Munich: Addison-Wesley; 1997.

[60] Breschi S, Malerba F, Eds. Clusters, networks and innovation. Oxford: Oxford Univ Press 2007
[61] Krämer G. Associations and organizations of the forest and wood industry of Germany. Methods for analysis and categorization [in German]. Hamburg: University of Hamburg; 1996.

[62] Brody S, Cash S, Dyke J, Thornton S. Motivations for the forestry industry to participate in collaborative ecosystem management initiatives. Forest Policy Econ 2006; 8: 123-134.

[63] Scholl A. Interviews. Social science method and communication science application [in German]. Konstanz: UVK Verlagsgesellschaft 2003.

[64] Mayer HO. Interviews and questionaire surveys [in German]. 2nd ed. Munich: Oldenbourg Wissenschaftsverlag 2004.

[65] Kies U, Mrosek T, Schultz A. An information system concerning stakeholders of the forest and wood industry. Case study of North Rhine-Westphalia [in German]. Allgemeine Forst Zeitschrift/Der Wald 2007; 6: 297-9.

(C) Mrosek et al.; Licensee Bentham Open.

This is an open access article licensed under the terms of the Creative Commons Attribution Non-Commercial License (http://creativecommons.org/licenses/by$\mathrm{nc} / 3.0 /$ ) which permits unrestricted, non-commercial use, distribution and reproduction in any medium, provided the work is properly cited. 